\title{
Bibliography
}

\section{Diabetes in the Mouse Due to Two Mutant Genes - a Bibliography}

\author{
J. Staats
}

The Jackson Laboratory, Bar Harbor, Maine, USA

Received: April 22, 1975, and in revised form: May 26, 1975

\begin{abstract}
Summary. A bibliography is presented of work involving the two diabetes-producing autosomal recessive mutations in the mouse, $d b$ and $d b^{2 J}$.
\end{abstract}

Key words: Diabetes mellitus, $d b, d b^{2 j}$, mutant genes, inbred mice.
The mutation diabetes $(d b)$ occurred in the C57BL/Ks inbred mouse strain at the Jackson Laboratory [1], and is inherited as a unit autosomal recessive with full penetrance. It is characterized in the homozygote by a metabolic disturbance resembling diabetes mellitus in man. Abnormal deposition of fat at 3 to 4 weeks of age is followed by hyperglycemia, polyuria, and glycosuria. The condition appears to develop biphasically. In the early stage there are marked increases in the plasma insulin level, the rates of lipogenesis, gluconeogenesis and glucose oxidation, and there is a reduction of B-cell granules in the islets of Langerhans with other changes suggestive of a compensating adaptation to increase insulin demand. The late stage is characterized by a near normal level of circulating insulin and a marked decrease in glucose utilization, but with a high rate of gluconeogenesis maintained. These findings suggest a defect in the peripheral utilization of insulin rather than in the synthesis and release of insulin [2].

A new mutant resembling both $d b$ and obese $(o b)$ was discovered in 1966, also at the Jackson Laboratory. By a series of appropriate crosses, the new mutant was shown to be an allele of $d b$ and was named diabetes-2J $\left(d b^{2 J}\right)$. Effects of the two alleles are similar, but $d b^{2 I}$ produces a milder pathological picture, at least on some genetic backgrounds [47]. Another mutant, named $d b^{3 J}$, arose in the $129 / \mathrm{J}$ strain at the Jacksor Laboratory.

In 1959, Falconer at Edinburgh announc 1 the mu tation adipose (ad) [81-84]. In 1972, $a d$ was showt. to be allelic with $d b$, and the designation was changed to $d b^{a d}$.

It is believed that the following is a reasonably complete listing of periodical articles on these muta- tions. Literature was searched to March 1975. Arrangement is chronological and alphabetical within years. The author would like to be informed of omissions.

1. Hummel, K. P., Dickie, M.M., Coleman, D.L.: Diabetes, a new

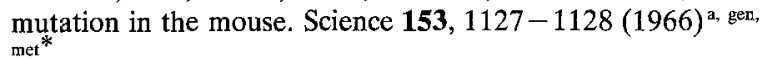

2. Coleman, D.L., Hummel, K.P.: Studies with the mutation, diabetes, in the mouse. Diabetologia 3, 238-248 (1967) ${ }^{\text {a, met }}$

3. Coleman, D.L., Hummel, K. P.: Lésions physiologiques et morphologiques caractérisant le diabète par mutation $d b$ chez la souris. J. Diabétol. Hôtel-Dieu 9, 19-30 (1968) a, met

4. Coleman, D. L., Hummel, K.P.: The mutation, diabetes, in the mouse. Proc. VIth Congr. Internat. Diabetes Fed., Stockholm July 30-Aug. 4, 1967, pp. 813-8201968 a, gen, met

5. Malaisse, W.J., Malaisse-Lagae, F., Coleman, D.L.: Insulin secretion in mice with an hereditary diabetes. Proc. Soc. exp. Biol. (N. Y.) 129, 65-69 (1968) a, met

6. Naeye, R.L.: Organ abnormalities in a diabetic mouse. Abstr. Amer. J. Path. 52, 41a-42a (1968) a, met

7. Renold, A.E.: Spontaneous diabetes and/or obesity in laboratory rodents. Advanc. Metab. Dis. 3, 49-84 (1968) a, c, e, gen, met

8. Renold, A.E.: Diabètes spontanés héréditaires chez les animaux; introduction. J. Diabétol. Hôtel-Dieu 9, 7-10 (1968) ${ }^{\mathrm{a}}$ c, gen, met

9. Stahl, S. S.: The periodontal structures in diabetic mice. J. oral Med. 23, 15-17 (1968) a, met

10. Chick, W.L.: Beta cell proliferation and DNA synthesis in diabetic mutant mice. Abstr. Fed. Proc. 28, 574 (1969) a, met

11. Chirvan-Nia, P., Bibal-Prot, P.: Etude comparée de différentes formes de diabète chez la souris. Compt. Rend. Acad. Sci. (Paris) 269, 1293-1296 (1969) a, met

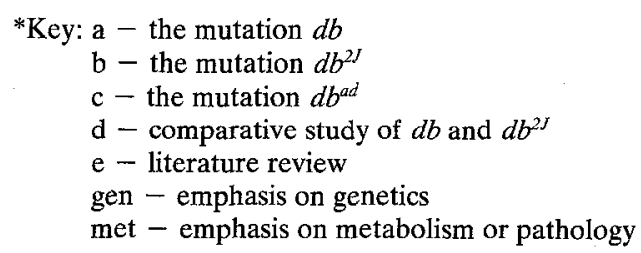


12. Coleman, D. L., Hummel, K.P.: Effects of parabiosis of normal with genetically diabetic mice. Amer. J. Physiol. 217, $1298-1304(1969)^{\mathrm{a}, \text { met }}$

13. Desjardins, C.: Pituitary growth hormone and its hypothalamic releasing factor in normal and genetically diabetic mice. Proc. Soc. exp. Biol. (N.Y.) 130, 1-4 (1969) ${ }^{\mathrm{a} \text {, met }}$

14. Dickie, M.M.: The genetics of diabetes mellitus in animals. Proc. 3rd Internat. Cong. Endocrinol., Mexico, D.F., 30 June-5 July, pp. 333-337 $1969^{\mathrm{a}, c \text {, gen }}$

15. Kupiecki, F.P.: Reduced adenosine 3',5'-monophosphate phosphodiesterase activity in the pancreas and adipose tissue of spontaneously diabetic mice. Life Sci. 8, 645-649 (1969) a, met

16. Like, A. A., Chick, W.L.: Mitotic division in pancreatic beta cells. Science 163, 941-943 (1969) ${ }^{\text {a, met }}$

17. Like, A.A., Coleman, D.L., Hummel, K.P.: Pancreatic islet studies in diabetic mutant mice. Abstr. Fed. Proc. 28, 574 $(1969)^{\mathrm{a}, \text { met }}$

18. Ratsimamanga, A.R., Rakoto, A., Chirvan-Nia, P.: Variations de l'activité de la surrénale dans différentes formes de diabète chez la souris. Compt. Rend. Acad. Sci. (Paris) 269, $1781-1784(1969)^{\text {a, met }}$

19. Steinmetz; J., Lowry, L., Yen, T.T. T.: An analysis of the lipolysis in vitro of obese-hyperglycaemic and diabetic mice. Diabetologia 5, 373-378 (1969) a, met

20. Yen, T.T.T., Steinmetz, J., Lowry, L.: Effect of obese and diabetes mutations on lipolysis in mice. Abstr. Fed. Proc. 28, $912(1969)^{\text {a, met }}$

21. Antoniades, H.N., Simon, J.D., Ettlinger, M.G.: Prolonged effect of adipose tissue extracts (ATE) on the blood glucose concentrations of nondiabetic and diabetic mice. Abstr. Fed. Proc. 29, $379(1969)^{\text {a, met }}$

22. Blake, R. L.: Hydrocortisone induction of tyrosine aminotransferase activity in genetically obese and diabetic mice-effects of a multiple dosage schedule. Biochem. Pharmacol. 19, $1508-1512(1970)^{\mathrm{a}, \text { met }}$

23. Chang, A.Y., Schneider, D. I.: Abnormalities in hepatic enzyme activities during development of diabetes in $d b$ mice. Diabetologia 6, 274-278 (1970) a, met

24. Chick, W.L., Like, A. A.: Studies in the diabetic mutant mouse. III. Physiological factors associated with alterations in beta cell proliferation. Diabetologia 6, 243-251 (1970) a, met

25. Chick, W.L., Like, A.A.: Studies in the diabetic mutant mouse. IV. DBM, a modified diabetic mutant produced by outcrossing of the original strain. Diabetologia 6, 252-256 (1970) ${ }^{\text {a, met }}$

26. Chick, W.L., Lavine, R.L., Like, A.A.: Studies in the diabetic mutant mouse. V. Glucose tolerance in mice homozygous and heterozygous for the diabetes $(d b)$ gene. Diabetologia 6, $257-262(1970)^{\text {a, met }}$

27. Coleman, D.L., Hummel, K.P.: The effects of hypothalamic lesions in genetically diabetic mice. Diabetologia 6, 263-267 $(1970)^{\text {a, met }}$

28. Dickie, M.M.: Genetics of animals with spontaneous diabetes. In: Early diabetes (eds. R. Camerini-Davalos, H.S. Cole), pp. 23-31. New York: Academic Press $1970^{\text {a, gen }}$

29. Like, A. A., Chick, W.L.: Studies in the diabetic mutant mouse. I. Light microscopy and radioautography of pancreatic islets. Diabetologia 6, 207-215 (1970) ${ }^{\text {a, mel }}$

30. Like, A. A., Chick, W. L.: Studies in the diabetic mutant mouse. II. Electron microscopy of pancreatic islets. Diabetologia 6 , $216-242(1970)^{\text {a, met }}$

31. Renold, A.E., Burr, I.: The pathogenesis of diabetes mellitus: possible usefulness of spontaneous hyperglycemic syndromes in animals. Calif. Med. 112, 23-24 (1970) ${ }^{\mathrm{a}, \mathrm{c} \text {, met }}$

32. Stauffacher, W., Orci, L., Amherdt, M., Lambert, A.E., Renold, A.E., Rouiller, C.: Le diabète spontané chez l'animal. Considérations sur la pathogénèse du syndrome aigu et sur la morphologie des lésions du syndrome chronique. Path. et Biol. 18, 539-549 (1970) a, c, met

33. Tsuji, S., Meier, H.: Lipolytic esterase activity of adipose tissue from mice with three types of hereditary obesity. Biochim. biophys. Acta (Amst.) 210, 420-424 (1970) (a, met $^{\text {a }}$

34. Westman, S.: Hereditary diabetes and obesity in laboratory animals. Abstr. Diabetologia 6, 655 (1970) ${ }^{\text {a, c, gen, met }}$

35. Wyse, B.M., Dulin, W.E.: The influence of age and dietary conditions on diabetes in the $d b$ mouse. Diabetologia 6 , $268-273(1970)^{\mathrm{a}, \text { met }}$

36. Yen, T.T.T., Steinmetz, J., Simpson, P.J.: Blood volume of obese $(o b / o b)$ and diabetic $(d b / d b)$ mice. Proc. Soc. exp. Biol. (N. Y.) 133, 307-308 (1970) a, met

37. Antoniades, H.N., Simon, J.D., Baile, C.A., Ettlinger, M.G.: Prolonged hypoglycemic effect of adipose tissue extracts (ATE) in nondiabetic and diabetic mice. Endocrinology 88, $1222-1229(1971)^{\text {a, met }}$

38. Bray, G.A., York, D.A.: Genetically transmitted obesity in rodents. Physiol. Rev. 51, 598-646 (1971) ${ }^{a, c}$, e, gen, met

39. Cathelineau, G.: Choix de l'animal pour les diabètes expérimentaux et spontanés. Expér. Anim. (Paris) 4, 189-200 $(1971)^{a, c}$

40. Chick, W.L., Like, A. A.: Effects of diet on pancreatic beta cell replication in mice with hereditary diabetes. Amer. J. Physiol. 221, 202-208 (1971) $)^{\text {a, met }}$

41. Renold, A.E., Burr, I.M., Stauffacher, W.: Experimental and spontaneous diabetes in animals; what is their relevance to human diabetes mellitus. Proc. roy. Soc. Med. 64, 613-617 $(1971)^{\mathrm{a}, \mathrm{c}, \text { met }}$

42. Stauffacher, W., Orci, L., Cameron, D.P., Burr, I. M., Renold, A.E.: Spontaneous hyperglycemia and/or obesity in laboratory rodents; an example of the possible usefulness of animal disease models with both genetic and environmental components. Recent Progr. Hormone Res. 27, 41-91 (1971) a, c, met

43. Strasser, H.K.: Defining the spontaneously diabetic laboratory rodent. In: ICLA IV Internat. Symp., pp. 44-59. Washington: Nat. Acad. Sci. $1971^{\text {a, }}$ c, met

44. Anapolle, S.E., Albright, J.T., Craft, F.O.: The ultrastructure of the gingiva in the diabetic mouse. Microvasc. Res. 4, $132-141 .(1972)^{a, \text { met }}$

45. Coleman, D.L., Hummel, K.P.: Comparison of the obesity syndromes of obese $(o b / o b)$ and diabetic $(d b / d b)$ mice. Abstr. Diabetologia 8, 49 (1972) $)^{\mathrm{a}, \text { met }}$

46. Fuller, J.L.: Genetic aspects of regulation of food intake. Advanc. psychosom. Med. 7, (Basel) 2-24 (1972) a, met

47. Hummel, K.P., Coleman, D.L., Lane, P.W.: The influence of genetic background on expression of mutations at the diabetes locus in the mouse. I. C57BL/KsJ and C57BL/6J strains. Biochem. Genet. 7, 1-13 (1972) a, b, d, gen

48. Johnson, P.R., Hirsch, J.: Cellularity of adipose depots in six strains of genetically obese mice. J. Lipid Res. 13, 2-11 $(1972)^{\text {a, met }}$

49. Johnson, P. R., Zucker, L. M., Hirsch, J.: Adipose tissue cellularity in genetic obesity. Abstr. Diabetologia 8, 51 (1972) a, met

50. Kandutsch, A. A., Coleman, D.L., Alpert, S.E.: Androgen effect of genetic and goldthioglucose-induced obesity. Experientia 28, 473-474 (1972) ${ }^{\text {a, met }}$

51. Like, A.A., Lavine, R.L., Poffenbarger, P.L., Chick, W.L.: Studies in the diabetic mutant mouse. VI. Evolution of glomerular lesions and associated proteinuria. Amer. J. Path. 66, $193-224(1972)^{\text {a, met }}$

52. Renold, A. E., Cameron, D.P., Amherdt, M., Stauffacher, W., Marliss, E., Orci, L., Rouiller, C.: Endocrine-metabolic anomalies in rodents with hyperglycemic syndromes of hereditary and/or environmental origin. Israel J. med. Sci. 8, 189-206 $(1972)^{\text {a, c, met }}$ 
53. Sprott, R.L.: Long-term studies of feeding behavior of obese, diabetic, and viable yellow mutant mice under ad lib. and operant conditions. Psychol. Rep. 30, 991-1003 (1972) ${ }^{\text {b }}$

54. Yen, T.T., Acton, J.M.: Locomotor activity of various types of genetically obese mice. Proc. Soc. exp. Biol. (N.Y.) 140, $647-650(1972)^{\mathrm{a}}$

55. Yen, T.T., Steinmetz, J.A.: Lipolysis of genetically obese and/ or hyperglycemic mice with reference to insulin response of adipose tissue. Horm. Metab. Res. 4, 331-337 (1972) a, met

56. Anapolle, S. E., Albright, J. T., Craft, F. O.: Continued study of the ultrastructure of the gingiva in the diabetic mouse. Microvasc. Res. 6, 44-50 (1973) a, met

57. Cameron, D.P., Stauffacher, W., Amherdt, M., Orci, L., Renold, A. E.: Kinetics of immunoreactive insulin release in obese hyperglycemic laboratory rodents. Endocrinology 92, $257-264(1973)^{\text {a, met }}$

58. Coleman, D.L.: Effects of parabiosis of obese with diabetes and normal mice. Diabetologia 9, 294-298 (1973) $)^{\text {b, met }}$

59. Cuendet, G.S., Wollheim, C.B., Cameron, D.P., Balant, L., Stauffacher, W., Marliss, E.B.: The fasted $o b / o b$ mouse: model for the metabolic response to fasting in man. Abstr. Diabetologia 9, $65(1973)^{\mathrm{a}, \text { met }}$

60. Herberg, L., Doppen, W., Major, E.: Strain specific differences in immunoreactive insulin secretion. Abstr. Z. Versuchstierk. $15,370(1973)^{a, \text { met }}$

61. Laube, H., Fussgänger, R.D., Maier, V. and Pfeiffer, E.F.: Hyperglucagonemia of the isolated perfused pancreas of diabetic mice $(d b / d b)$. Diabetologia 9, 400-402 (1973) a, met

62. Yen, T.T. and Acton, J.M.: Stimulation of locomotor activity of genetically obese mice by amphetamine. Experientia 29, $1297-1298(1973)^{a}$

63. Boquist, L.: Mechanisms of insulin release; evidence for a secretory defect in genetically diabetic mice. Abstr. Acta endocr. 77 (Suppl. 190), 10-11 (1974) a, met

64. Boquist, L., Hellman, B., Lernmark, Å., Täljedal, I.-B.: Influence of the mutation 'diabetes' on insulin release and islet morphology in mice of different genetic backgrounds. J. Cell. Biol. 62, 77-89 (1974) $)^{a, b, \text { met }}$

65. Boquist, L., Hellman, B., Lernmark, $\AA$., Täljedal, I.-B.: Content of adenosine $3^{\prime}, 5^{\prime}$-cyclic monophosphate in the pancreatic islets of mice with a hereditary defect of insulin secretion. Biochem. biophys. Res. Commun. 60, 1391-1396 (1974) $)^{\mathrm{a}, \mathrm{b}}$, met

66. Chan, T.M., Exton, J.H.: Hepatic carbohydrate metabolism in the genetically diabetic $(d b / d b)$ mice. Abstr. Fed. Proc. 33, $1315(1974)^{\text {a, met }}$

67. Coleman, D.L., Hummel, K.P.: Hyperinsulinemia in pre-weaning diabetes $(d b)$ mice. Diabetologia 10,607-610 (1974) $)^{\text {a, met }}$

68. ElGeneidy, A.K., Stallard, R.E., Fillios, L.C., Goldman, H.M.: Periodontal and vascular alterations; their relationship to the changes in tissue glucose and glycogen in diabetic mice.J. Periodont. 45, 395-401 (1974) a, met

69. Gunnarsson, R.: Defective insulin biosynthesis in the diabetic mouse. Abstr. Acta endocr. 77 (Suppl. 190), 18 (1974) a, met
70. Kupiecki, F.P., Adams, L.D.: The lipolytic system in adipose tissue of Toronto-KK and C57BL/KsJ diabetic mice. Adenylate cyclase, phosphodiesterase and protein kinase activities. Diabetologia 10, 633-637 (1974) a, met

71. Novis, D., Korson, R.: Capillary basement membranes of muscle in diabetic mice (genetic and virally induced). Abstr. Fed. Proc. 33, 607 (1974) ${ }^{\text {a, met }}$

72. Neville, D.: Receptors for polypeptide hormones: direct studies of insulin binding to purified liver plasma membranes. In Vitro 9, 445-454 (1974)

73. Soret, M.G., Kupiecki, F.P., Wyse, B.M.: Epididymal fat pad alterations in mice with spontaneous obesity and diabetes and with chemically induced obesity. Diabetologia 10, 639-648 $(1974)^{\text {a, met }}$

74. Stern, J.S., Greenwood, M.R. C.: A review of development of adipose cellularity in man and animals. Fed. Proc. 33, $1952-1955(1974)^{\text {a, met }}$

75. Thenen, S.W., Mayer, J.: A comparative study of circulating insulin concentration and adipose tissue glycerokinase activity in experimental obesity. Abstr. Fed. Proc. 33, 701 (1974) $^{\text {a met }}$

76. Yen, T.T., Fuller, R.W., Pearson, D.V.: The response of 'obese' $(o b / o b)$ and 'diabetic' $(d b / d b)$ mice to treatments that influence body temperature. Comp. Biochem. Physiol. 49A, $377-385(1974)^{\text {a, met }}$

77. Chan, T.M., Exton, J.H.: Glucose metabolism and insulin sensitivity in livers of genetically diabetic $(d b / d b)$ mice. Abstr. Fed. Proc. 34, $334(1975)^{\text {a, met }}$

78. Kawaguchi, T., Matsushita, H.: Electrophoretic patterns of serum albumins collected from hereditary obese and diabetic mice. Endocrinology 96, 409-415 (1975) a, met

79. Koenig, R.J., Cerami, A.: Glycosylation of hemoglobin in the diabetic mouse. Abstr. Fed. Proc. 34, 335 (1975) ${ }^{\text {a, met }}$

80. Kuo, J.F., Davis, C.W.: Decreased levels of cyclic GMP-dependent protein kinase in the heart of hypertensive rats and in the liver of diabetic mice. Abstr. Fed. Proc. 34, $262(1975)^{\text {a, met }}$

81. Falconer, D.S., Isaacson, J.H.: Adipose, a new inherited obesity of the mouse. J. Hered. 50, 290-292 (1959) c, gen, met

82. Batt, R.A.L., Harrison, G.A.: Features of the "adipose" mouse. Abstr. Heredity 15, $335(1960)^{\mathrm{c} \text {, met }}$

83. Batt, R.A.L., Harrison, G.A.: The reproductive system of the adipose mouse. J. Hered. 54, 135-138 (1963) ${ }^{\circ}$

84. Bulfield, G.: Genetic control of metabolism: enzyme studies of the obese and adipose mutants in the mouse. Genet. Res. 20, $51-64(1972)^{\text {c, met }}$

Acknowledgements. Preparation of this paper was supported in part by grants GB27487 and BMS 75-03397 from the National Science Foundation. I thank Dr. Douglas Coleman for reviewing this paper.

Miss Joan Staats

The Jackson Laboratory

Bar Harbor, Maine 04609

USA 